Ekuitas: Jurnal Pendidikan Ekonomi

Volume 9, Number 1, Tahun 2021, pp. 69-78

P-ISSN : 2354-6107 E-ISSN : 2549-2292

DOI : $10.23887 /$ ekuitas.v9i1.27034

Open Access: https://ejournal.undiksha.ac.id/index.php/EKU

\title{
Persepsi Orang Tua Siswa Terhadap Biaya Pendidikan
}

\author{
Putu Yulia Apsari Dewi ${ }^{*}$, Luh Indrayani² \\ 1,2Universitas Pendidikan Ganesha, Singaraja - Indonesia
}

\author{
A R T I C L E I N F O \\ Article history: \\ Received July, 182020 \\ Received in revised form \\ June, 152021 \\ Accepted June, 152021 \\ Available online June, 28 \\ 2021 \\ Kata Kunci: \\ Biaya pendidikan, dana \\ BOS, persepsi orang tua. \\ Keywords: \\ Education fee, BOS funds, \\ parents' perceptions.
}

\section{A B S T R A K}

Biaya yang harus dikeluarkan untuk mengenyam pendidikan tidaklah sedikit, khususnya di kota-kota besar seperti Kota Singaraja. Maka dari itu masalah biaya masih menjadi pertimbangan bagi seseorang untuk mengenyam pendidikan khususnya bagi masyarakat yang berlatar belakang ekonomi kurang mampu. Masalah tersebut tentunya memerlukan bantuan dari pihak pemerintah. Sejak tahun 2005 pemerintah telah mengucurkan bantuan dana pendidikan melalui dana BOS. Permasalahan yang timbul saat ini yaitu dana BOS hanya cukup digunakan untuk membiayai operasional pendidikan, dana tersebut tidak mampu mengganti semua biaya pribadi yang harus dikeluarkan untuk memenuhi kebutuhan anak di sekolah. Hal tersebut menimbulkan berbagai pandangan dari orang tua siswa, baik itu positif maupun negatif. Maka dari itu penelitian ini bertujuan untuk mengetahui bagaimana persepsi orang tua siswa mengenai biaya pendidikan khususnya di Kota Singaraja. Penelitian ini menggunakan jenis penelitian deskriptif dengan pendekatan kualitatif. Hasil penelitian ini menyimpulkan bagaimana persepsi orang tua siswa SMA terhadap biaya pendidikan di Kota Singaraja. Secara umum, para orang tua merasa masih banyak biaya yang dikeluarkan walaupun telah menerima bantuan dana BOS. Kendati demikian, mereka tidak akan keberatan mengeluarkan biaya pendidikan karena mereka sadar bahwa pendidikan merupakan hal yang sangat penting untuk masa depan anaknya.

\section{A B S T R A C T}

The cost spent on education fee cannot be considered low, especially in big cities like Singaraja City. Education fee still becomes a major consideration for people to obtain an education, particularly for those who have low economic background. This problem certainly requires government's help. Since 2005, the government has distributed educational funding through BOS funds. The problem occurs because BOS fund is only sufficient to fulfill the educational operations, it cannot cover all personal costs that must be spent to fulfill students' needs in school. This arises various perceptions from students' parents, both positive and negative. Therefore, this study aimed to determine how parents' perceptions towards education fee, especially in Singaraja City. This research implemented descriptive qualitative approach. The results of this study concluded how high school students' parents' perceptions towards the educational fee in Singaraja city. In general, parents argue that there are still many costs that they spend despite receiving BOS funding. Nevertheless, they do not mind spending certain cost for education purposes because they realize that education is important for their children's future.

Copyright (C) Ekuitas: Jurnal Pendidikan Ekonomi. All rights reserved.

\footnotetext{
* Corresponding author.

E-mail : yuliaapsari77@gmail.com (Putu Yulia Apsari Dewi)
} 


\section{Pendahuluan}

Pendidikan dapat diartikan sebagai media yang berarti untuk menumbuhkan sumber daya manusia (SDM) yang mandiri, bermutu, demokratis, sejahtera, dan bebas dari kemiskinan. Pendidikan dapat kita lihat dari dua aspek yaitu teoritis dan praktis. Dilihat dari sudut teoritis, pendidikan bisa bermakna sebagai cara mendewasakan setiap manusia. Sedangkan apabila kita lihat dari sudut praktisnya, pendidikan dapat dilihat dari kelembagaan (Suharsaputra, 2013). Pendidikan adalah suatu investasi yang bersifat jangka panjang dan mempunyai peran penting untuk proses peningkatan kualitas SDM (Atmanti, 2005). Dimana kualitas SDM yang maju akan diperoleh melalui suatu proses pendidikan.

Pendidikan diperlukan oleh setiap orang untuk meningkatkan kualitas dirinya. Kualitas pendidikan harus mendapatkan perhatian bersama karena masih diperlukannya cara tepat agar kualitas pendidikan meningkat sehingga mampu bersaing di persaingan global dalam segi pendidikan. Persaingan tersebut makin menunjukkan peningkatan hasil yang baik (Ekosiswoyo, 2016). Dalam proses untuk mencapai kualitas pendidikan yang baik, tidak bisa dipungkiri bahwa diperlukan biaya yang besar agar hal tersebut dapat tercapai. Khasanah (2018) mengungkapkan biaya pendidikan adalah suatu komponen wajib untuk pendidikan agar segala sesuatu dapat dimudahkan dalam proses pendidikan. Biaya untuk pendidikan adalah semua hal yang dikeluarkan guna terselenggaranya proses pendidikan. Hal tersebut ialah salah satu unsur dasar yang paling dibutuhkan dalam penyelenggaraan pendidikan. Apabila tidak terdapat biaya pendidikan yang mendukung dan memadai, hal tersebut menyebabkan proses pendidikan tidak berjalan dengan baik (Susilawati et al., 2014). Penelitian yang dilakukan Prasojo (2012) mengemukakan bahwa masalah yang muncul dalam penyelenggaran pendidikan, jika kita diperhatikan pasti akan berujung pada satu bagian yang menjadi dasar yaitu biaya pendidikan yang umumnya diperlukan dalam jumlah yang besar untuk penyelenggaraan proses pendidikan.

Dalam penyelenggaraan proses pendidikan, dibutuhkan biaya-biaya yang wajib dikeluarkan tidak hanya biaya langsung tetapi juga terdapat yang bersifat tidak langsung. Biaya yang memengaruhi proses pendidikan secara langsung dinamakan dengan biaya langsung. Contoh dari biaya tersebut seperti biaya untuk membeli buku perpustakaan, biaya untuk membeli alat-alat dan perlengkapan sekolah guna menunjang proses belajar, dan juga biaya untuk membayar upah guru dan pegawai. Di luar biaya langsung tersebut, terdapat juga biaya tidak langsung yang dikeluarkan di dalam mendukung penyelenggaran pendidikan yang dikeluarkan secara pribadi seperti uang saku, biaya transport, biaya internet, dan biaya hidup (Suharsaputra, 2013).

Menurut hasil penelitian Atmaja et al. (2016) biaya pendidikan sebagian besarnya digunakan untuk membayar gaji guru dan pegawai sekitar 75\% - 80\%, dan sisanya untuk non-gaji yaitu penyelenggaraan proses pendidikan. Jumlah biaya yang harus dikeluarkan untuk mengenyam pendidikan tidaklah sedikit, tingginya jenjang pendidikan yang ditempuh akan meningkatkan pula dana pendidikan yang dibutuhkan. Maka dari itu masalah biaya masih menjadi pertimbangan bagi seseorang untuk mengenyam pendidikan khususnya bagi masyarakat yang berlatar belakang ekonomi kurang mampu. Masalah tersebut juga dipaparkan dalam penelitian yang dilakukan oleh Idris (2010) dijelaskan bahwa biaya pendidikan di Indonesia masih mahal dan masih menjadi masalah untuk masyarakat menengah ke bawah. Azhari \& Kurniady (2016) menyebutkan bahwa sumber dana yang masih tersendat merupakan salah satu masalah dalam dunia pendidikan. Masalah tersebut tentunya memerlukan bantuan dari pihak pemerintah.

Peran pemerintah telah terlihat sejak tahun 2005 dengan mengucurkan bantuan dana pendidikan lewat Progam Bantuan Operasional Sekolah atau yang kita kenal Dana BOS. Bantuan ini dikeluarkan dengan tujuan memberi kebebasan untuk biaya pendidikan bagi siswa yang dirasa tidak mampu, dan memberikan keringanan biaya untuk siswa lainnya. Hal itu bermaksud untuk menyediakan layanan pendidikan yang baik dan bermutu untuk para siswa sekolah dasar. Program ini diharapkan berperan dalam pencapaian penuntasan wajib belajar dua belas tahun. Pada program wajib belajar dua belas tahun, SMA merupakan jenjang tertinggi yang menghabiskan biaya pendidikan paling besar sehingga mendapatkan dana BOS lebih banyak daripada jenjang dibawahnya. Banyak atau sedikitnya biaya pendidikan pada tingkatan satuan tertentu dipengaruhi oleh berbagai indikator mutu pendidikan yaitu angka putus sekolah, angka partisipasi, prestasi belajar dan tinggal kelas (Usman, 2016). Berdasarkan hal tersebut peneliti memfokuskan penelitian ini untuk biaya pendidikan pada jenjang SMA khususnya pada sekolah negeri karena sekolah negeri sudah mendapatkan bantuan dana dari pemerintah namun tetap saja orangtua siswa harus membayarkan sejumlah dana pendidikan.

Permasalahan yang timbul saat ini yaitu dana BOS hanya cukup digunakan untuk membiayai operasional pendidikan, dana tersebut tidak mampu mengganti semua biaya pribadi yang harus dikeluarkan untuk memenuhi kebutuhan anak di sekolah. Fironika K. (2005) juga memaparkan bahwa pemerintah tidak lepas tangan dalam membiayai pendidikan lewat bantuan dana BOS, namun bantuan 
tersebut sifatnya masih terbatas. Pada kenyataannya, banyak biaya yang bersifat tidak langsung yang harus dikeluarkan untuk mengenyam pendidikan di sekolah, seperti biaya untuk membeli seragam sekolah, alat tulis, iuran tambahan, biaya les, uang saku, dan biaya penunjang pendidikan lainnya. Untuk memenuhi kebutuhan tersebut, orang tua dari siswa itu sendiri yang memiliki peran untuk membiayai pendidikan yang bersifat dominan selain bantuan dana dari pemerintah. Pada umunya, orang tua siswa akan mempersiapkan biaya untuk pelaksanaan proses pendidikan karena bermaksud menginginkan agar anaknya memiliki kualitas yang baik. Namun, jika pengeluaran biaya untuk pendidikan tersebut terlampau tinggi, hal tersebut akan menjadi pertimbangan.

Masalah tingginya biaya pendidikan tentunya juga dialami para orang tua di Kota Singaraja. Kota Singaraja merupakan kota besar yang menjadi pusat dari Kabupaten Buleleng. Dilihat dari historis dan banyaknya sekolah untuk mengenyam pendidikan di kota ini membuat Kota Singaraja dikenal sebagai kota pendidikan. Kota ini didatangi oleh banyak pelajar yang berasal dari berbagai daerah untuk mengenyam pendidikan. Hal tersebut menyebabkan pertumbuhan ekonomi di Kota Singaraja meningkat sehingga biaya-biaya yang dikeluarkan untuk mengenyam pendidikan di kota ini juga tidak sedikit.

Berdasarkan observasi awal yang dilakukan peneliti, biaya yang dikeluarkan oleh anak yang mengenyam pendidikan di sekolah menengah atas (SMA) lebih besar dari biaya pendidikan pada jenjang dibawahnya. Menurut siswa SMA di Kota Singaraja yang peneliti wawancara, biaya yang dikeluarkan masih banyak walaupun telah diberikan dana BOS di sekolah mereka, bahkan beberapa anak yang kurang mampu juga mendapatkan bantuan dana berupa beasiswa Program Indonesia Pintar (PIP). Biaya-biaya tersebut berupa uang saku, biaya pembelian seragam sekolah dan perlengkapan belajar di sekolah, biaya untuk membeli buku LKS, biaya les, biaya transport, biaya yang dikeluarkan untuk membuat tugas. Selain itu, terdapat sejumlah iuran sekolah yang harus dibayarkan, bukan hanya iuran untuk sekolah tetapi terdapat juga iuran untuk angkatan dan iuran untuk kelas. Terdapat juga biaya-biaya yang dikeluarkan untuk kegiatan di luar kelas seperti study tour, tirta yatra, dan perayaan ulang tahun sekolah.

Orang tua sebagai sumber pendanaan pendidikan selain pemerintah, berperan penting untuk memenuhi kebutuhan-kebutuhan tersebut. Muncul berbagai pandangan orang tua siswa terhadap biaya pendidikan, ada yang beranggapan bahwa biaya pendidikan memang banyak sehingga membebani para orang tua, selain itu ada pula yang beranggapan bahwa biaya tersebut memang seharusnya dikeluarkan dan orang tua tidak keberatan untuk mengeluarkan biaya tersebut dengan harapan anaknya mendapatkan kualitas pendidikan yang baik. Karena itu, dalam penelitian ini peneliti bermaksud untuk mengetahui bagaimana persepsi orang tua mengenai biaya pendidikan tersebut.

Penelitian ini yaitu hanya memfokuskan pada persepsi orang tua siswa SMA Negeri di Kota Singaraja terhadap biaya pendidikan. Orang tua siswa dipilih sebagai subjek karena orang tua sebagai penyumbang dana terbesar bagi pendidikan setelah pemerintah. Tujuan dari penelitian ini dimaksudkan untuk mengetahui persepsi orang tua siswa terhadap biaya pendidikan dilihat dari faktor karakteristik pribadi, faktor situasional, dan faktor dalam target. Setiap hari manusia tentunya melakukan interaksi dengan lingkungannya yang mengakibatkan munculnya stimulus atau rangsangan terhadap suatu objek. Penilaian yang berbeda-beda akan mucul dari setiap orang mengenai suatu objek yang sama, hal itu terjadi karena adanya persepsi.

Anggraini R (2013) menyebutkan arti persepsi yakni reaksi menyeleksi stimulus yang berasal dari lingkungannya atau proses menstrukturkan serta menginterpretasikan tanggapan. Tanggapan itu diperoleh oleh indra seseorang agar mempunyai arti pada kontak hidupnya. Persepsi orang tua siswa terhadap biaya pendidikan terbentuk karena adanya stimulus yang diterima dari hasil melihat, mendengar, merasakan sesuatu dari apa yang tampak dari suatu objek yaitu biaya pendidikan. Maka dari itu, orang tua siswa dipilih sebagai subyek dalam penelitian ini karena mereka yang terlibat langsung dalam pembiayaan pendidikan dan merasakan efek dari mahalnya biaya pendidikan.

Dalam mempersepsikan sesuatu, terdapat faktor-faktor yang berpengaruh di dalamnya. Pada penelitian ini, peneliti menggunakan teori Robins (2005) yang menguraikan faktor-faktor terlibat pada proses penerjemahan kesan-kesan indra hingga membentuk persepsi. Faktor pertama adalah faktor dari karakteristik pribadi atau pemersepsi merupakan cara pandang pribadi tanpa mengetahui sifat-sifat sebenarnya yang dimiliki oleh objek. Karakteristik pribadi yang dimaksud disini yaitu sikap, motif, kepentingan, pengalaman, dan penghargaan (ekspektasi). Kedua adalah faktor situasional mempengaruhi persepsi, seperti waktu kita melihat objek, keadaan atau kondisi seseorang saat ia menilai objek juga mempengaruhi cara pandang seseorang pada objek tertentu.Ketiga yaitu faktor dalam target tentu mempengaruhi apa yang kita nilai. Kita akan cenderung memfokuskan perhatian pada sesuatu yang kita anggap menarik. Persepsi yang kita hasilkan juga sering kali mengelompokan sesuatu yang mirip sebagai kesamaan. Faktor dalam target yang mempengaruhi penilaian kita seperti hal baru, dan latar belakang.

Adapun objek yang dipersepsikan dalam penelitian ini yaitu biaya pendidikan. Dilihat dari segi pendidikan, yang diartikan sebagai biaya pendidikan yakni semua sumber daya milik satuan pendidikan 
yang dapat diukur melalui uang atau unit lain dengan tujuan mendapatkan keuntungan dari kependidikan yang selaras dengan tujuan satuan pendidikan. Biaya pendidikan adalah faktor penentu agar pendidikan atau pembelajaran terselenggara dengan baik dalam suatu organisasi pendidikan seperti sekolah (Suharsaputra, 2013). Biaya pendidikan melingkupi gaji guru termasuk peningkatan dan profesional guru, biaya untuk pengadaan dan perbaikan sarana ruang belajar, biaya pembelian peralatan serta buku pelajaran, pengeluaran untuk kegiatan pelaksanaan pendidikan, supervisi, dan kegiatan lainnya seperti ekstrakurikuler. Jadi, dari pengertian-pengertian di atas dapat kita simpulkan yaitu biaya pendidikan adalah pengeluaran dalam berbagai bentuk yang dikorbankan untuk menyokong penyelenggaraan pendidikan.

Menurut Suharsaputra (2013) biaya yang dikeluarkan dalam lembaga pendidikan pada umumnya ialah biaya langsung (direct cost) dan biaya tidak langsung (indirect cost). Biaya langsung merupakan pengeluran yang terlibat langsung untuk proses produksi pendidikan yang bisa membuat mutu pendidikan meningkat secara langsung. Biaya langsung memengaruhi produk pendidikan. Bagian dari biaya langsung yang dimaksud yaitu gaji untuk guru dan pegawai lainnya, pengadaan buku baik itu buku pelajaran atau perpustakaan, peralatan dan perlengkapan belajar mengajar, fasilitas laboratorium. Dalam proses pengajaran, hal yang harus dimiliki oleh biaya langsung yaitu: berhubungan erat pada hasil, bersifat tidak terhindarkan, kuantitatif atau dapat dihitung, serta mampu melaksanakan proses pendidikan. Indirect cost (biaya tidak langsung) yaitu berupa biaya penunjang hidup, biaya transportasi, dan biaya lainnya. Selain dua biaya tersebut, juga terdapat social cost dan private cost. Social cost yang dengan kata lain disebut biaya publik, merupakan biaya yang digunakan untuk proses pendidikan yang bersumber dari masyarakat. Private cost yaitu biaya pendidikan yang didapatkan dari keluarga siswa itu sendiri untuk pendidikan anaknya, yang didalamnya termasuk forgone opportunities (biaya kesempatan yang hilang).

Hal tersebut hampir sama dengan apa yang dijelaskan Supriadi (2006) biaya pendidikan dibagi kedalam dua jenis yaitu biaya langsung dan biaya tidak langsung. Biaya langsung (direct cost) adalah berbagai bentuk pengeluaran guna menunjang penyelenggaraan pendidikan secara langsung. Biaya langsung meliputi pengeluaran untuk membeli alat-alat dan sarana belajar, dan gaji guru baik yang dikeluarkan oleh siswa sendiri, orang tua, ataupun pemerintah. Sedangkan biaya tidak langsung (indirect cost) yaitu pengeluaran yang bersifat tidak langsung dalam mendukung proses pendidikan namun bisa memungkinkan proses pendidikan tersebut berlangsung di sekolah, biaya tidak langsung tersebut dapat berupa uang jajan, biaya transportasi, biaya hidup siswa, biaya kesehatan, dan harga kesempatan (opportunity cost).

\section{Metode}

Penelitian ini menggunakan jenis penelitian deskriptif pendekatan kualitatif, yang mendeskripsikan persepsi orang tua SMA mengenai biaya pendidikan di Kota Singaraja, Kabupaten Buleleng, Provinsi Bali. Orang tua siswa SMA khususnya sekolah negeri di Kota Singaraja menjadi populasi dari penelitian ini, karena peneliti ingin mencari tahu persepsi orang tua siswa SMA terhadap biaya pendidikan. Adapun banyaknya populasi dalam penelitian ini yaitu sebanyak 4.186 orang yang berasal dari orang tua siswa SMAN 1 Singaraja, SMAN 2 Singaraja, SMAN 3 Singaraja, dan SMAN 4 Singaraja. Selanjutnya ditentukan banyaknya sampel yang akan menjadi informan dalam penelitian ini bersumber dari jumlah populasi. Menurut Sugiyono (2016) sampel dapat ditentukan menggunakan rumus slovin dengan perhitungan sebagai berikut.

$$
\mathrm{n}=\frac{\mathrm{N}}{1+\mathrm{N}(\mathrm{e})^{2}}
$$

Keterangan:

$\mathrm{n}$ = banyaknya responden sebagai sampel

$\mathrm{N}$ = banyaknya populasi

$\mathrm{e}=$ tingkat dispensasi ketelitian kesalahan terhadap pengambilan sampel yang masih dapat ditoleransi

Berdasarkan penjelasan di atas, dapat kita ketahui jumlah responden melalui perhitungan sebagai berikut.

Diketahui:

$\mathrm{N}=4186$ 


$$
\begin{aligned}
& \mathrm{e}=5 \%(0,05) \\
& \mathrm{n}=\frac{4186}{1+4186(0,05)^{2}} \\
& \mathrm{n}=\frac{4186}{11,465} \\
& \mathrm{n}=365,11
\end{aligned}
$$

Hasil perhitungan di atas menunjukkan angka 365,11 dan dibulatkan menjadi 370 orang sebagai sampel dari populasi adalah orang tua siswa SMA Negeri di Kota Singaraja sebanyak 4.186 orang. Dalam menentukan sampel pada masing-masing sekolah, digunakan teknik sampling non random sampling yakni dilakukan dengan mengambil sampel dari anggota populasi, namun tidak semua anggota populasi digunakan sebagai sampel. Teknik non random sampling yang digunakan yaitu proportional sampling. Teknik ini mampu mewakili karakteristik populasi yang berasal dari empat sekolah dengan mengambil sampel sesuai porsi masing-masing sekolah. Penentuan sampel menggunakan teknik proportional sampling didapat dengan rumus seperti di bawah.

$$
\mathrm{n}=\frac{\text { jumlah populasi tiap sekolah }}{\text { jumlah populasi keseluruhan }} \times \text { jumlah sampel }
$$

Dari rumus di atas didapatkan porsi sampel untuk masing-masing sekolah yaitu 94 orang tua siswa untuk SMAN 1 Singaraja, 90 orang tua siswa untuk SMAN 2 Singaraja, 89 orang tua siswa untuk SMAN 3 Singaraja, dan 97 orang tua siswa untuk SMAN 4 Singaraja.

Data yang digunakan pada penelitian ini yaitu jenis data kualitatif yang dideskriptif dengan katakata untuk menarik kesimpulan. Sumber data yang digunakan ialah bersumber dari data primer dan data sekunder. Data primer dari penelitian ini bersumber dari jawaban kuesioner yang disebarkan kepada orang tua siswa SMA Negeri di Kota Singaraja sebagai responden. Sedangkan data sekunder ialah data yang didapatkan dengan cara tidak langsung dari data yang sudah ada di Dinas Pendidikan seperti data jumlah sekolah dan jumlah siswa SMA Negeri yang ada di Kota Singaraja.

Instrumen yang digunakan pada penelitian ini yaitu kuesioner guna mendapatkan data kuantitatif dari persepsi orang tua siswa Sekolah Menengah Atas terhadap pembiayaan pendidikan. Persepsi tersebut berupa jawaban dari pertanyaan-pertanyaan yang diberi skor dengan menggunakan skala likert. Kuesioner dalam penelitian, memakai lima pilihan jawaban, yaitu untuk jawaban sangat setuju mendapatkan nilai tertinggi 5 , dan jawaban tidak setuju dengan skor terendah 1 . Sebelum instrumen tersebut dipergunakan, uji validitas dan reliabilitas dilakukan pada instrumen agar instrumen yang dipergunakan relevan dan dapat dipercaya. Uji Validitas memperlihatkan daya instrumen dalam hal mengukur subjek dan memperoleh data yang absah. Instrumen dalam penelitian ini diuji menggunakan program SPSS 20.0 yaitu dengan membandingkan $r$ hitung output dari SPSS dengan $r$ tabel yang telah ada. Instrumen akan dinyatakan valid ketika $r$ hitung lebih besar daripada $r$ tabel. Reliabilitas merupakan tingkat kestabilan dari hasil yang didapat oleh suatu alat ukur, walaupun digunakan secara terusmenerus untuk suatu subjek yang sama atau berbeda. Oleh karena itu, instrumen dinyatakan reliabel apabila dapat mengukur suatu hal yang memperoleh hasil yang konsisten. Instrumen dalam penelitian ini diuji memakai program SPSS 20.0 dengan memperhatikan nilai koefisien reliabilitas atau Alpha yaitu lebih dari 0,6.

Metode pengumpulan data yang digunakan dalam penelitian ini, yaitu kuesioner dan wawancara tidak terstruktur untuk mengetahui jawaban responden berupa persepsi terhadap pembiayaan pendidikan. Kuesioner disebarkan kepada orang tua siswa di SMA Negeri yang menjadi sumber informasi pada penelitian ini. Kuesioner yang disebarkan berupa susunan pertanyaan yang dapat mengungkapkan bagaimana persepsi informan terhadap biaya pendidikan.

Setelah data terkumpul, data kemudian dianalisis menggunakan teknik analisis deskriptif dengan tujuan mencari tahu bagaimana persepsi orang tua siswa SMA terhadap biaya pendidikan di Kota Singaraja ditinjau dari faktor karakteristik pribadi, faktor situasional, dan faktor dalam target. Menurut Irianto (2004), langkah-langkah yang digunakan dalam analisis deskriptif yang pertama yaitu menentukan skor tertinggi dan terendah yang didapat dari seluruh jawaban yang didapat dari informan melalui kuesioner. Hal tersebut dilakukan dengan mengalikan nilai tertinggi dengan jumlah pertanyaan dikalikan dengan jumlah responden begitu sebaliknya untuk skor terendah dicari dengan rumus nilai terendah dikalikan jumlah pertanyaan dikalikan jumlah responden. Setelah mendapatkan skor tertinggi dan skor terendah ditentukan interval untuk persepsi orang tua siswa SMA di Kota Singaraja dengan metode mengurangi skor tertinggi dengan skor terendah, kemudian dibagi jumlah kategori. Persepsi 
orang tua siswa dalam penelitian ini dibagi ke menjadi lima kategori, yakni sangat setuju, setuju, raguragu, kurang setuju, dan tidak setuju.

\section{Hasil dan pembahasan Hasil Penelitian}

Berdasarkan data berupa jawaban yang didapatkan dari responden pada kuesioner, diperoleh hasil seperti di bawah.

Persepsi orang tua siswa SMA terhadap biaya pendidikan di Kota Singaraja ditinjau dari dimensi faktor karakteristik pribadi seperti sikap, motif, kepentingan, dan pengalaman yaitu.

Tabel 1. Hasil Analisis Data Persepsi Orang Tua Siswa SMA Terhadap Biaya Pendidikan di Kota Singaraja Ditinjau dari Dimensi Faktor Karakteristik Pribadi

\begin{tabular}{lccc}
\hline \multicolumn{1}{c}{ Dimensi } & Skor & Rentang Skor & Kategori \\
\hline Faktor karakteristik pribadi & 16.322 & $13.838-17.093$ & Setuju \\
\hline Total & 16.322 & $13.838-17.093$ & Setuju \\
\hline
\end{tabular}

Berdasarkan tabel hasil analisis data di atas, persepsi orang tua siswa SMA terhadap biaya pendidikan di Kota Singaraja ditinjau dari dimensi faktor karakteristik pribadi memperoleh skor 16.322 yang berada pada rentang skor 13.838 - 17.093, skor tersebut termasuk ke dalam kategori setuju. Secara umum, dilihat dari sikap, motif, kepentingan, dan pengalaman, orang tua setuju dengan pentingnya biaya pendidikan. Selain itu, para orang tua juga setuju akan pentingnya menyiapkan biaya pendidikan anak untuk masa depan.

Data di atas menunjukkan bahwa orang tua setuju dengan biaya pendidikan adalah hal penting yang harus dikorbankan guna menunjang proses pendidikan anak di sekolah. Biaya pendidikan adalah salah satu kunci sistem pembelajaran dapat terlaksana dengan baik. Orang tua setuju bahwa biaya pendidikan harus dikeluarkan agar anaknya mendapat pendidikan yang baik. Menurut mereka biaya pendidikan di Kota Singaraja masih banyak walaupun telah mendapatkan bantuan BOS dari pemerintah. Kendati demikian, mereka tidak keberatan mengeluarkan sejumlah biaya untuk pendidikan anaknya karena mereka sadar pendidikan merupakan sesuatu yang sangat potensial dan penting. Mereka memiliki harapan dengan sejumlah biaya yang dikeluarkan, anaknya dapat mengikuti pembelajaran dengan baik dan menjadi orang yang berkualitas. Mereka juga setuju bahwa biaya pendidikan terus meningkat seiring berjalannya waktu sehingga harus disiapkan sebelum anak memulai masa pendidikan mengingat biaya pendidikan yang jumlahnya tidak sedikit. Mereka setuju bahwa semakin tinggi biaya pendidikan maka semakin bagus kualitas pendidikan.

Persepsi orang tua siswa SMA terhadap biaya pendidikan di Kota Singaraja ditinjau dari dimensi faktor situasional seperti waktu, keadaan tempat, dan keadaan sosial yaitu sebagai berikut.

Tabel 2. Hasil Analisis Data Persepsi Orang Tua Siswa SMA Terhadap Biaya Pendidikan di Kota Singaraja Ditinjau dari Dimensi Faktor Situasional

\begin{tabular}{lccc}
\hline \multicolumn{1}{c}{ Dimensi } & Skor & Rentang Skor & Kategori \\
\hline Faktor situasional & 11.325 & $10.064-12.431$ & Setuju \\
\hline Total & 11.325 & $10.064-12.431$ & Setuju \\
\hline
\end{tabular}

Berdasarkan tabel hasil analisis di atas, persepsi orang tua siswa SMA terhadap biaya pendidikan di Kota Singaraja ditinjau dari faktor situasional mendapatkan skor 11.325 dan berada pada rentang skor $10.064-12.431$. Hasil tersebut masuk ke dalam kategori setuju sehingga menunjukkan respon positif dari para orang tua siswa SMA terhadap biaya pendidikan di Kota Singaraja.

Dilihat dari faktor situasional seperti letak sekolah, waktu, fasilitas sekolah, pelayanan yang didapat, dan lingkungan di sekitar siswa, orang tua setuju bahwa hal-hal tersebut berpengaruh terhadap besar kecilnya biaya pendidikan. Secara umum orang tua siswa setuju bahwa biaya pendidikan sekarang lebih mahal jika dibandingkan dengan biaya pendidikan yang dirasakan orang tua terdahulu. Oleh sebab 
itu orang tua harus mempersiapkan tabungan untuk kelanjutan pendidikan anaknya, mereka juga setuju bahwa semakin tinggi pendidikan anak maka biaya pendidikan yang dikeluarkan semakin banyak.

Orang tua setuju bahwa letak sekolah mempengaruhi biaya pendidikan yang dikeluarkan. Selain itu, mereka juga beranggapan bahwa semakin mahal biaya pendidikan maka semakin bagus pula fasilitas dan pelayanan yang didapatkan oleh anaknya. Selain itu, ruang lingkup pertemanan siswa dan kegiatan ekstra kurikuler berpengaruh terhadap biaya pendidikan.

Persepsi orang tua siswa SMA terhadap biaya pendidikan di Kota Singaraja ditinjau dari dimensi faktor dalam target seperti latar belakang yaitu sebagai berikut

Tabel 3. Hasil Analisis Data Persepsi Orang Tua Siswa SMA Terhadap Biaya Pendidikan di Kota Singaraja Ditinjau dari Dimensi Faktor dalam Target

\begin{tabular}{lclc}
\hline \multicolumn{1}{c}{ Dimensi } & Skor & Rentang Skor & Kategori \\
\hline Faktor dalam target & 4.080 & $3.774-4.661$ & Setuju \\
\hline Total & 4.080 & $3.774-4.661$ & Setuju \\
\hline
\end{tabular}

Berdasarkan tabel hasil analisis data di atas, persepsi orang tua siswa SMA terhadap biaya pendidikan di Kota Singaraja ditinjau dari faktor dalam target mendapatkan skor 4.080 yang berada pada rentang skor 3.774 - 4.661. Hal tersebut masuk ke dalam kategori setuju yang menunjukkan bahwa terdapat respon positif dari orang tua.

Dilihat dari faktor dalam target seperti latar belakang orang tua, mereka setuju bahwa orang tua merasa mampu dan tidak keberatan mengeluarkan biaya pendidikan untuk anaknya agar pendidikan yang diperoleh anaknya dapat melebihi pendidikan orang tua.

\section{Pembahasan}

Hasil penelitian mendapatkan beragam jawaban responden baik setuju maupun tidak setuju. Para orang tua siswa memiliki pandangan masing-masing terhadap bagaimana biaya pendidikan di Kota Singaraja. Dilihat dari jawaban kuesioner yang diperoleh, sebagian besar orang tua merasa setuju ada pula yang tidak setuju terhadap berbagai pernyataan yang ada. Namun secara keseluruhan penelitian ini menghasilkan respon yang positif, artinya orang tua setuju dengan berbagai pernyataan di dalam kuesioner mengenai biaya pendidikan di Kota Singaraja. Berdasarkan tiga dimensi yang ada yaitu faktor dari karakteristik pribadi, faktor situasional, dan faktor dalam target, secara garis besar menghasilkan jawaban setuju dari para orang tua.

Ditinjau dari dimensi pertama yaitu faktor karakteristik pribadi dapat dilihat dari sikap, motif, kepentingan, dan pengalaman pemersepsi. Para orang tua setuju bahwa biaya pendidikan seperti biaya pembelian perlengkapan sekolah, pengeluaran untuk membeli buku, dan biaya untuk fasilitas kegiatan belajar ialah biaya yang wajib dikeluarkan sebagai penunjang proses pembelajaran anak dalam mendapatkan pendidikan. Selain biaya yang disebutkan tadi terdapat juga biaya-biaya untuk menunjang proses pendidikan seperti biaya les diluar sekolah,transportasi, uang saku, dan biaya untuk kegiatan ekstrakurikuler. Mereka sebagai orang tua mengetahui betul bahwa segala kegiatan pembelajaran yang dilaksanakan baik di dalam ataupun luar sekolah tentu membutuhkan biaya agar dapat dilaksanakan dengan baik. Selaras dengan apa yang dihasilkan dari penelitian Fadillah et al. (2015), yang mengungkapkan bahwa biaya pendidikan adalah faktor amat penting pada proses peningkatan mutu pendidikan. Para orang tua beranggapan dengan mengeluarkan sejumlah biaya untuk pendidikan anak merupakan salah satu cara untuk mendukung anak agar menjadi orang yang berkualitas baik.

Disisi lain para orang tua setuju bahwa biaya untuk menunjang pendidikan yang harus dikeluarkan di Kota Singaraja khususnya untuk SMA Negeri masih terbilang banyak walaupun telah mendapatkan dana BOS dari pemerintah. Bantuan tersebut telah diatur dalam Permendikbud No 3 Tahun 2019. Dalam peraturan tersebut tercantum jumlah bantuan dana yang diberikan yakni untuk jenjang SMA mendapatkan bantuan dana sebesar Rp. 1.400.000,00 per satu peserta didik setiap tahunnya. Bantuan tersebut dianggarkan untuk biaya operasional sekolah. Dana tersebut telah meringankan pengeluaran dari para orang tua walaupun masih banyak biaya untuk memenuhi kebutuhan dalam pembelajaran.

Hasil penelitian menunjukkan bahwa para orang tua siswa setuju bahwa mereka merasa tidak keberatan untuk mengeluarkan sejumlah biaya walaupun banyak biaya yang masih harus dikeluarkan. Hal tersebut dikarenakan para orang tua siswa memiliki motif yaitu berharap mendapatkan hasil dari apa yang dikeluarkan untuk pendidikan. Mereka berharap bahwa biaya yang dikeluarkan dapat memenuhi 
kebutuhan anak dalam proses pembelajaran. Jika pelaksanaan pendidikan anaknya berjalan $\mathrm{d}$ baik dan anaknya mendapatkan pendidikan layak, maka kecenderungan anaknya menjadi orang yang sukses akan lebih banyak. Seperti yang kita ketahui, banyak program bimbingan belajar diluar sekolah yang bisa membantu anak dalam proses pendidikan yang lebih baik. Hal tersebut tentunya membutuhkan biaya lebih. Pada orang tua ikhlas mengeluarkan uang yang banyak, dengan harapan anaknya mendapatkan pendidikan yang lebih baik lagi.

Para orang tua siswa setuju bahwa biaya pendidikan memang harus wajib dikeluarkan karena pada zaman sekarang pendidikan merupakan hal yang penting dan wajib untuk dipenuhi. Berdasarkan pengalaman yang dimiliki orang tua, mereka setuju bahwa biaya pendidikan semakin hari semakin meningkat jumlahnya. Munir (2013), dalam penelitiannya mengungkapkan biaya pendidikan masih mahal dan hal tersebut menjadi beban bagi masyarakat. Mereka juga setuju bahwa biaya pendidikan harus dipikirkan dan dipersiapkan sebelum anak memulai masa pendidikan di sekolah. Mereka juga beranggapan bahwa semakin tinggi biaya pendidikan yang harus dikelurkan maka semakin bagus pula kualitas peserta didik yang dihasilkan dari suatu pendidikan. Sejalan dengan hasil penelitian Sanjiwani (2012) yang menyimpulkan biaya pendidikan berpengaruh besar terhadap mutu proses belajar anak di sekolah.

Selanjutnya ditinjau dari dimensi kedua yaitu faktor situasional, secara umum para orang tua siswa juga setuju dengan beberapa pernyataan yang ada pada kuesioner. Dilihat dari waktunya biaya pendidikan dari masa ke masa tentu mengalami perubahan. Mereka setuju bahwa biaya pendidikan pada saat mereka mengenyam pendidikan jauh berbeda dengan biaya pendidikan pada saat ini. Biaya pendidikan saat ini tentunya lebih banyak dikeluarkan jika dibandingkan pendidikan terdahulu yang dienyam orang tua. Dengan kesadaran seperti itu mereka setuju bahwa mereka sebagai orang tua harus mempersiapkan tabungan, deposito, maupun asuransi untuk kelanjutan pendidikan anaknya di masa depan karena mereka tidak dapat mengetahui dan mengira berapa biaya pendidikan yang akan dikeluarkan di masa depan. Hal tersebut juga diungkapkan dalam penelitian Firdaus (2016), yaitu pentingnya merencanakan biaya pendidikan anak untuk meringankan dan mengantisipasi tingginya biaya pendidikan di masa yang akan datang. Kristiani (2011) juga mengingatkan bahwa menyiapkan uang untuk sekolah anak ialah sesuatu yang diharuskan dan mutlak disiapkan para keluarga. Terlebih mereka setuju bahwa semakin tinggi atau panjang masa pendidikan yang ditempuh anaknya maka semakin besar pula biaya pendidikan yang harus dihabiskan.

Para orang tua siswa juga setuju bahwa biaya pendidikan yang dikeluarkan dipengaruhi oleh keadaan sekitar seperti letak sekolah, ruang lingkup pertemanan, fasilitas yang didapat, dan berbagai kegiatan lainnya yang mendukung proses pembelajaran. Mereka setuju bahwa letak sekolah mempengaruhi besarnya biaya pendidikan. Hal tersebut dapat terlihat pada uang transport, semakin jauh letak sekolah semakin banyak uang transport yang harus dikeluarkan. Kegiatan lainnya seperti kegiatan ekstrakurikuler juga membutuhkan tambahan biaya baik itu biaya untuk membeli perlengkapan pendukung atau pun uang saku dan transport.

Orang tua siswa juga setuju bahwa banyaknya biaya pendidikan yang dikorbankan berbanding lurus dengan fasilitas serta layanan pendidikan yang diperoleh. Jika biaya pendidikan tinggi maka semakin lengkap fasilitas yang disediakan sekolah untuk mendukung proses pembelajaran dalam sekolah. Hal itu juga dijelaskan oleh Sanjiwani (2012) pada penelitiannya, yaitu biaya yang dikeluarkan untuk pendidikan akan sebanding dengan fasilitas yang di dapat. Semakin banyak biaya yang keluar maka semakin banyak pula fasilitas pendidikan yang tersedia. Selain itu, mereka juga setuju bahwa semakin tinggi biaya pendidikan maka semakin bagus pelayanan dari tenaga pendidik yang didapat.

Biaya pendidikan juga dipengaruhi oleh ruang lingkup pertemanan anak di sekolah. Para orang tua setuju dengan pernyataan tersebut karena menurut mereka ruang lingkup pertemanan anak mempengaruhi seberapa banyak uang saku yang harus dikeluarkan. Kegiatan di luar kelas seperti ekstrakurikuler juga dapat mempengaruhi jumlah biaya yang dikeluarkan. Para orang tua setuju bahwa dengan adanya kegiatan tersebut menyebabkan pengeluaran lebih seperti uang saku atau biaya keperluan untuk mendukung kegiatan tersebut.

Ditinjau dari dimensi ketiga yaitu faktor dalam target seperti latar belakang, orang tua siswa setuju bahwa biaya pendidikan merupakan hal yang sangat penting. Mereka merasa mampu membiayai pendidikan anaknya sehingga tidak merasa keberatan mengeluarkan sejumlah uang untuk pendidikan anaknya. Mereka tidak mempermasalahkan anaknya menghabiskan sejumlah uang untuk pendidikan karena mereka sebagai orang tua juga telah melewati masa tersebut, mereka merasa sebagai orang yang berpendidikan harus menyekolahkan anaknya setinggi-tingginya. Mereka berharap anaknya dapat menempuh pendidikan lebih tinggi dari pendidikan orang tuanya.

Secara umum penelitian ini menjelaskan persepsi orang tua siswa SMA terhadap biaya pendidikan di Kota Singaraja. Sebagian besar orang tua setuju dengan beberapa pernyataan yang disajikan 
oleh peneliti sesuai apa yang diuraikan di atas. Berdasarkan apa yang telah dijelaskan tadi, terdapat kesesuaian dengan apa yang dijelaskan oleh Robins (2005) yaitu bagaimana persepsi orang tua tentang biaya pendidikan dipengaruhi oleh faktor karakteristik pribadi pemersepsi seperti sikap, motif, kepentingan, dan pengalaman, faktor situasional seperti waktu, keadaan tempat, dan keadaan sosial pemersepsi saat ia menilai, dan faktor dalam target seperti latar belakang pemersepsi.

Para orang tua siswa sadar akan pentingnya pendidikan tanpa dorongan dari siapa pun, mereka tidak keberatan dan akan terus berupaya untuk dapat memenuhi kebutuhan pendidikan anaknya di sekolah. Mereka dengan sadar mengakui pendidikan adalah investasi penting dan wajib untuk masa depan anak yang lebih baik. Mereka mengeluarkan sejumlah uang untuk biaya pendidikan anaknya, dengan harapan anak dapat menjadi pribadi yang mempunyai kualitas baik. Sebagian besar dari mereka setuju dengan pentingnya menyiapkan dana sejak dini untuk pendidikan anaknya. Mereka merasa terbantu dengan adanya bantuan dana BOS dari pemerintah. Perlu diketahui anggaran yang disediakan pemerintah lewat dana BOS tersebut masih bersifat terbatas untuk memenuhi kebutuhan belajar mengajar. Walaupun jumlah yang ditanggung orang tua masih cukup banyak, setidaknya dana BOS tersebut dapat mengurangi beban untuk biaya pendidikan yang harus dikeluarkan para orang tua siswa.

\section{Simpulan dan saran Simpulan}

Dapat disimpulkan bahwa persepsi orang tua siswa SMA terhadap biaya pendidikan di Kota Singaraja. Menurut para orang tua, biaya pendidikan merupakan hal yang sangat penting, mereka setuju bahwa biaya pendidikan seperti biaya untuk perlengkapan sekolah, biaya pembelian buku, dan biaya untuk fasilitas kegiatan belajar merupakan hal yang harus dikeluarkan untuk menunjang proses pembelajaran anak di sekolah. Para orang tua tidak keberatan mengeluarkan sejumlah uang untuk pendidikan anaknya karena mengharapkan anaknya mendapatkan pendidikan yang bermutu sehingga anaknya mampu menjadi pribadi yang berkualitas. Kendati demikian, mereka merasa bahwa biaya pendidikan di Kota Singaraja masih banyak walaupun telah mendapatkan bantuan dana BOS.

Dana BOS yang diterima hanya terbatas untuk mendanai operasional sekolah seperti biaya untuk membeli buku, gaji guru dan pegawai, serta biaya yang bersifat operasional.

Adanya persepsi bahwa biaya pendidikan masih mahal, para orang tua siswa setuju bahwa biaya pendidikan harus disiapkan dengan matang sebelum anak memulai masa sekolah. Menurut mereka biaya pendidikan akan semakin mahal seiring dengan lama anak menempuh pendidikan. Mereka juga menyadari bahwa biaya pendidikan akan mengalami peningkatan seiring berjalannya waktu. Secara umum, para orang tua tidak akan keberatan mengeluarkan biaya pendidikan dan akan berupaya memenuhi kebutuhan pendidikan anak karena mereka sadar untuk menyiapkan masa depan anak yang baik diperlukan biaya yang tidak sedikit.

\section{Saran}

Para orang tua disarankan agar menyiapkan biaya pendidikan dengan matang sebelum anak memasuki masa sekolah, dan juga menyiapkan biaya cadangan untuk mengantisipasi kenaikan biaya pendidikan yang tidak bisa diprediksi di masa mendatang. Itu sangat berguna dan dapat memberi kemudahan di masa depan untuk seandainya biaya pendidikan terus meningkat.dan jumlahnya tidak sedikit. Dengan munculnya persepsi orang tua siswa terhadap biaya pendidikan seperti apa yang telah dipaparkan di atas, diharapkkan hasil penelitian ini mampu menjadi acuan pemerintah untuk membuat kebijakan-kebijakan yang mampu mengurangi beban masyarakat khususnya untuk menunjang pendidikan.

\section{Daftar Rujukan}

Anggraini R. (2013). Persepsi Orangtua terhadap Anak Berkebutuhan Khusus. E-JUPEKhu OJurnal Ilmiah Pendidikan Khusus), $258-265$. http://ejournal.unp.ac.id/index.php/jupekhu/article/viewFile/951/807

Atmaja, T. E. R., Harun, C. Z., \& Ibrahim, S. (2016). Analisis Penetapan Standar Biaya Pendidikan. Jurnal Administrasi Pendidikan, $4(1)$,

119-128. http://jurnal.untan.ac.id/index.php/jpdpb/article/view/8167/8148

Atmanti, D. H. (2005). Investasi sumber daya manusia melalui pendidikan. Jurnal Dinamika Pembangunan (JDP), 
arini_Dwi_Atmanti_(OK).pdf

Azhari, U. L., \& Kurniady, D. A. (2016). Manajemen Pembiayaan Pendidikan, Fasilitas Pembelajaran, dan Mutu Sekolah. Jurnal Administrasi Pendidikan Universitas Pendidikan Indonesia, 23(2), 26-36. https://ejournal.upi.edu/index.php/JAPSPs/article/view/5631

Ekosiswoyo, R. (2016). Kepemimpinan Kepala Sekolah yang Efektif Kunci Pencapaian Kualitas Pendidikan. Jurnal Ilmu Pendidikan, 14(2), 76-82. https://doi.org/10.17977/jip.v14i2.24

Fadillah, N., Agung, A., Agung, G., \& Yudana, I. M. (2015). Analisis Biaya Pendidikan Dan Hubungannya Dengan Mutu Pendidikan Pada SMPNegeri 2 Sukadasa Tahun Pelajaran 2013/2014. E-Journal Program Pascasarjana Universitas Pendidikan Ganesha Program Studi Administrasi Pendidikan, 6(1), 11.

Firdaus, F. (2016). Persepsi Pegawai Uin Syarif Hidayatullah Jakarta Mengenai Perencanaan Biaya Pendidikan Anak. Al-Iqtishad: Journal of Islamic Economics, 2(1). https://doi.org/10.15408/aiq.v2i1.2479

Fironika K., R. (2005). PEMBIAYAAN PENDIDIKAN DI INDONESIA. Jurnal Ilmiah Pendidikan Dasar, 2(1), 43-64. http://jurnal.unissula.ac.id/index.php/pendas/article/view/755

Idris, R. (2010). Apbn Pendidikan Dan Mahalnya Biaya Pendidikan. Lentera Pendidikan: Jurnal Ilmu Tarbiyah Dan Keguruan, 13(1), 92-110. https://doi.org/10.24252/lp.2010v13n1a7

Irianto, A. (2004). Statistik (Konsep Dasar dan Aplikasinya). Kencana.

Khasanah, N. (2018). Biaya Dan Manfaat Pendidikan. Jurnal Mitra Manajemen, 2(5), 397-405.

Kristiani, F. (2011). PERHITUNGAN PERKIRAAN BIAYA PENDIDIKAN ANAK. Bina Ekonomi, 15(2), 66-75. http://journal.unpar.ac.id/index.php/BinaEkonomi/article/view/783

Munir, A. (2013). Manajemen Pembiayaan Pendidikan dalam Perspektif Islam. Jurnal At-Ta'dib, 8(2), 223239. https://doi.org/http://dx.doi.org/10.21111/at-tadib.v8i2.502

Prasojo, L. D. (2012). Financial Resources Sebagai Faktor Penentu Dalam Implementasi Kebijakan Pendidikan. Jurnal Internasional Manajemen Pendidikan, 4(02), 19-27.

Robins, S. P. (2005). Organizational Behavior Prentice hall. Toronto.

Sanjiwani, I. (2012). Analisis Biaya Pendidikan Dan Dampaknya Terhadap Kualitas Proses Pembelajaran Dan Aspirasi Pendidikan Siswa (Studi Tentang Persepsi Para Siswa Sma Dwijendra Denpasar Tahun Pelajaran 2011/2012). Jurnal Administrasi Pendidikan, 3(2). https://doi.org/10.23887/japi.v3i2.459

Sugiyono, P. D. (2016). Metode Penelitian Kuantitatif, Kualitatif,dan R\&D. In Alfabeta, cv. Alfabeta.

Suharsaputra, U. (2013). Administrasi Pendidikan. PT Refika Aditama.

Supriadi, D. (2006). Satuan Biaya Pendidikan Dasar dan Menengah. PT. Remaja Rosdakarya.

Susilawati, N. L., Yudana, M., \& Natajaya, N. (2014). ANALISIS BIAYA PENDIDIKAN PADA SMP CIPTA DHARMA. E-Journal Program Pascasarjana Universitas Pendidikan Ganesha Program Studi Administrasi Pendidikan, 5(2).

Usman, J. (2016). URGENSI MANAJEMEN PEMBIAYAAN DALAM PENINGKATAN MUTU PENDIDIKAN MADRASAH. Tadris Jurnal Pendidikan Islam, 11(2), 219-246. http://ejournal.stainpamekasan.ac.id/index.php/tadris/article/view/1170 